\title{
Traditional Utilization and Chemical Composition of Major Browse Species in Range Lands of Mieso, Ethiopia
}

\author{
Welay K*, Nigatu L and Animut G \\ Haramaya University, School of Animal and Range Sciences, P.O box 138, Dire Dawa, \\ Ethiopia
}

*Corresponding author: Kiros Welay, Haramaya University, School of Animal and Range Sciences. P.0 box 138, Dire Dawa, Ethiopia, Email: kirosw47@gmail.com

\begin{tabular}{|c|}
\hline Research Article \\
Volume 3 Issue 9 \\
Received Date: September 17, 2018 \\
Published Date: October 11, 2018 \\
\hline
\end{tabular}

\begin{abstract}
The study was conducted in Mieso district, Ethiopia to assess traditional utilization and nutritive value of major browse species. Six major browse species were selected based on traditional uses, palatability and preference by animals with the help of skilled field assistant and elders. Leaves, pods, twigs and fruits were the plant parts utilized by livestock. Browse species also had many uses such as a source of fire wood, medicinal values and the majority of fruits were consumed by both human and livestock. Significant difference $(\mathrm{P}<0.05)$ was observed in $\mathrm{CP}, \mathrm{NDF}, \mathrm{ADF}$ contents among browse species. The highest CP was observed in Grewia ferruginea $(19 \pm 0.12 \%)$ and Grewia tenax $(18.7 \pm 0.57)$. The lowest $(\mathrm{P}<0.05) \mathrm{CP}$ was noted for Rhus natalensis $(15.5 \pm 0.19 \%)$. The present result suggests that browse species have a valuable role in feeding of animals and other worthy traditional uses.
\end{abstract}

Keywords: Browse Plants; Nutritive Values; Traditional Uses

\section{Introduction}

Browse plants, beside grasses, constitute one of the cheapest sources of feed for ruminants [1]. Their ever greenness and nutritional abundance provides for year round provision of fodder [2]. Most browse species have the advantage of maintaining their greenness and nutritive value throughout the dry season when herbaceous vegetation dry up and deteriorate both in quality and quantity. Trees and shrubs have been used for generations as multipurpose resources in many parts of the world [3]. Moreover, browsers can consume various parts of woody plants: leaves, twigs, thorns, bulbs, tubers, roots, flowers, seedpods and fruits [4].
In areas where the dry season lasts for long time, like in semi-arid and arid lands, trees and shrubs are a good source of supplementary nitrogen. The major use of foliage browse species is as a source of crude protein (CP). This quality of browse species is most useful during the dry season when most of the range grasses and other herbaceous annuals are no more producing the needed forage biomass [5]. The ability of most browses to remain green for longer time is attributed to their deep roots that enable them to extract water and nutrient resources from deep in the soil profile. Moreover, leguminous browse species fix atmospheric nitrogen, and this improves soil fertility that can be utilized by the companion or subsequent crops grown in the area [6]. 


\section{Open Access Journal of Agricultural Research}

Indigenous browse species have also high persistence in their respective areas [7]. Likewise, the pastoral communities have developed indigenous knowledge to utilize the woody vegetation for economic purposes [8]. Dawit, et al. also found that Afar and Tigray region of Ethiopia prioritize the uses of indigenous shrubs and trees differently [9]. However, the extensive utilization of the woody plants have increased pressure on the native vegetation, resulting in degradation of the resources due to over-utilization by the pastoral communities and overbrowsing by livestock and game animals [10]. As a result, encroachment by weeds and undesirable woody plants have become a threat to the pastoral production systems in the Horn of Africa, especially in eastern Ethiopia $[11,12]$. Pastoral environments are also typified by high levels of unpredictable variations in feed availability where forage availability fluctuates over time and space. This fluctuation is also reflected in gross production where forage production may range from zero to several tons per hectare depending on rainfall [13]. Survival in rangelands involves seizing opportunities when and where they exist and avoiding hazards, characteristics of opportunistic management. Sustainable utilization of available resources in rangelands requires tracking and matching the available resources with animal density

Mieso is one of the districts of Oromiya found in the rangelands of northeast and extensive grazing areas of the eastern Ethiopia, with 196,026 hectare (ha) total land area, practicing pastoral and agro-pastoral system. The major feed resource comes from rangelands which cover about 73,658 ha (38\%) of the total land area [14]. The relative high densities of livestock have results in overgrazing of rangeland, which causes progressive deterioration of the vegetation cover and, in consequence, a deficient supply of animal fodder. Feed scarcity is indicated as a factor responsible for the lower reproductive and growth performance of animals especially during the dry season [15]. Therefore, to alleviate the ruminant feed supply problems, looking for potential feed resources, particularly those which survive during the dry season, deserve due attention. In this regard, the use of browse species may have a greater potential in contributing towards alleviating the current feed shortage in natural rangelands of the country. Several studies have noted the importance of these plants in the arid and semi-arid areas of the world $[5,16]$. Therefore, this study is designed with the objective of assessing traditional utilization and evaluating nutritive value of major browse species in the study district.

\section{Material and Method}

\section{Description of the Study Area}

The study was conducted in Mieso district of West Hararghe Oromia Regional State. The total land area of the district is 196,026 ha [14]. The district's altitude ranges from 900 to 1600 meter above sea level. The mean annual temperature varies between 240C-280C. Agro ecologically, the district is classified as semi-arid "Kola". The mean annual rainfall ranges from 400 to $900 \mathrm{~mm}$, with an average of about $700 \mathrm{~mm}$ [14]. The area receives a bimodal rainfall where small rains occur between March and April while the main rains occur between July and September. Most of the rainfall is within only few months and remain dry for most of the months of the year. A study by Zelalem indicated that vegetation types of the study area are broadly being described as thorny bush and shrub dominated grassland [17]. The vegetation cover constitutes herbaceous perennials and annuals such as Pennisetum, Lintonia, Chrysopogon, Erigeron and small to medium-sized Acacia dominated woody plants

\section{Study Site Selection and Data Collection Methods}

Site selection was done between July and September (2010) based on the extent of area coverage and abundance of the major browse species as identified through open discussions made with community members, elders and districts Pastoral and Agro-Pastoral Office Experts. This was enriched with information on these species through literature review. Accordingly 18 female and 75 male household heads from three kebeles were identified randomly and interviewed independently. Based on the information obtained from community members, elders and districts Pastoral and Agro-Pastoral Office Experts, a structured questioner was designed and a single-visit formal survey method was followed to gather the necessary information [18]. Identifying of major browse species were conducted through, pastoralists' selection criteria such as traditional uses, dominance, palatability and preference by animals. Thirty two browse species were identified in the district. However, based on the criteria sated above, only six of them were selected for the traditional utilization and chemical analysis. Samples were collected at the end of rainy season (i.e. September to October 2010) as most species were at their flowering and/or seedling stages. Each browse species were collected from three representative sites (kebeles) called Gumbi, Fayyo, and 


\section{Open Access Journal of Agricultural Research}

Obensa and pooled in one for chemical analysis. Knowledgeable elders and skilled field assistant were consulted to identify individual shrubs and tree of each browse species by their vernacular names and those that cannot be identified with scientific name on the field were registered using vernacular name, collected and pressed with plant press and then transported to Haramaya University Herbarium for proper identification and nomenclature. Nomenclature of the plant species followed the Flora of Ethiopia and the Flora of Tropical East Africa $[19,20]$.

\section{Traditional Utilization of Major Browse Species}

Traditional uses of major browse species in the study area were documented and assessed with the aid of participatory discussions made with elder pastoralists. Besides Information on traditional uses of each major browse species were gathered through questionnaire prepared for this purpose.

\section{Sample Collection and Chemical Analysis of the Major Browse Species}

Foliage samples were taken from the upper, middle and lower strata for each browse species. The samples were air dried in a well-ventilated room until transported to Haramaya University Nutrition Laboratory and further dried in an oven at $600 \mathrm{C}$ for 72 hours. Then the samples from each browse species were ground separately in a Willey mill to pass through $1 \mathrm{~mm}$ sieve to carry out the chemical analysis. Samples were analyzed for dry matter (DM), ash, Ether extract (EE) and crude protein (CP) according to the procedures of AOAC [21]. The neutral detergent fiber (NDF), acid detergent fiber (ADF) and acid detergent lignin (ADL) of each sample were also analyzed, according to the procedure described by VanSoest and Robertson [22].

\section{Data Analysis}

Statistical Package for the Social Sciences was used to summarize the data and simple descriptive statistics such as mean, standard deviation and percentile for traditional uses of major browse species [23]. Data on chemical composition were analyzed using the general linear model procedure of SAS [24]. Mean differences were tested using Tukey.

The model used for chemical composition of major browse species was;

$\mathrm{Y}_{\mathrm{ij}}=\mu+\mathrm{si}+\mathrm{e}_{\mathrm{ij}, \text {, }}$
Where,

$\mathrm{Y}_{\mathrm{ij}}=$ Response variable

$\mu=$ Overall mean

$\mathrm{si}=$ Browse species effect

$\mathrm{e}_{\mathrm{ij}}=$ Random error

\section{Results And Discussion}

\section{Utilization of Major Browses Species}

Six major browse species were selected based on the opinion of respondents for the traditional utilization (Table 1). Those are; Acacia mellifera, Grewia ferruginea, Grewia tembensis, Grewia tenax, Rhus natalensis and Ziziphus mauritiana. According to information generated during group discussion, foliages of those browse plants were consumed directly from the live plant and lopped to weak animals. This is similar to Solomon, et al. reported from Abergelle woreda of Tigray Region [25].

\begin{tabular}{|c|c|c|}
\hline Scientific Name & Vernacular name & Family name \\
\hline Acacia mellifera & Sopheensa & Memosoideae \\
\hline Grewia ferruginea & Midhengurre & Tiliaceae \\
\hline Grewia tembensis & Ashedo & Tiliaceae \\
\hline Grewia tenax & Dhakka & Tiliaceae \\
\hline Rhus natalensis & Doboobessa & Anacardiaceae \\
\hline Ziziphus mauritiana & Qurqura & Rhamnaceae \\
\hline
\end{tabular}

Table 1: Six major browse species selected in Mieso district.

\section{Livestock Feeding Preferences on Major Browse Species}

Browse species were consumed preferentially by certain livestock species. Accordingly, cattle and sheep generally showed a more preference for Grewia ferruginea and Grewia tenax (Table 2). Group discussants also indicated that milking cows fed Grewia ferruginea gives higher milk production. This is might be because of the plant has highest crude protein content comparing to other browse plants (table 4). Leaves and pods of Acacia mellifera and Ziziphus mauritiana were markedly preferred by camel and goats. Similarly, Teferi et al. reported that Acacia species and Ziziphus spina-christi, were not highly preferred by cattle, particularly when they were presented with a choice [26]. Group discussants also noted that, Rhus natalensis was the best and most preferred browse species by camel. Moreovere, as shown in (table 2) leaves of all those browse plants were more preferred than the other plant parts. 


\section{Open Access Journal of Agricultural Research}

\begin{tabular}{|c|c|c|c|c|c|c|c|c|c|c|c|c|c|}
\hline Browse species & A.mellifera & \multicolumn{1}{c|}{ G.ferruginea } & \multicolumn{2}{c|}{ G. tembensis } & \multicolumn{2}{c|}{ G. tenax } & \multicolumn{2}{|c|}{ Rhus natalensis } & \multicolumn{2}{|c|}{ Z.mauritiana } \\
\hline Species of animal & $\mathrm{N}$ & $\%$ & $\mathrm{~N}$ & $\%$ & $\mathrm{~N}$ & $\%$ & $\mathrm{~N}$ & $\%$ & $\mathrm{~N}$ & $\%$ & $\mathrm{~N}$ & $\%$ \\
\hline Goat and sheep & 5 & 5.4 & 3 & 3.2 & 3 & 3.2 & 7 & 7.5 & 1 & 1.1 & 6 & 6.5 \\
\hline Sheep and cattle & 1 & 1.1 & 31 & 33.3 & 6 & 6.5 & 12 & 12.9 & 0 & 0 & 3 & 3.2 \\
\hline Goat and camel & 86 & 92.4 & 8 & 8.6 & 16 & 17.2 & 12 & 12.9 & 73 & 78.5 & 80 & 86 \\
\hline \multicolumn{8}{|c|}{ Preferred plant parts } \\
\hline Leaves and pods & 80 & 86 & 1 & 1.1 & 7 & 7.5 & 4 & 4.3 & 0 & 0 & 5 & 5.4 \\
\hline Leaves only & 7 & 7.5 & 79 & 84.9 & 83 & 89.2 & 70 & 75.3 & 79 & 84.9 & 55 & 59 \\
\hline Fruits only & 0 & 0 & 0 & 0 & 0 & 0 & 4 & 4.3 & 9 & 9.7 & 6 & 6.5 \\
\hline Twigs & 6 & 6.5 & 6 & 6.5 & 1 & 1.1 & 4 & 4.3 & 0 & 0 & 11 & 12 \\
\hline Leaves and fruits & 0 & 0 & 7 & 7.5 & 2 & 2.2 & 11 & 11.8 & 5 & 5.4 & 16 & 17 \\
\hline
\end{tabular}

$\mathrm{N}=$ number of respondents

Table 2: Major browse species favored by livestock species in Mieso district ( $\mathrm{N}=93$ ).

\section{Traditional Utilizations of Major Browse Species in Mieso District}

Beside the main source of feed for livestock, browse species are also utilized in the daily life of pastoralists in the study district; including construction materials, firewood, medicinal values, fencing and livestock shelter (Table3). This is in line with results of previous studies Coppock; Amaha; Lishan and Helen in Somali regional state, Teshome, et al. in Rayitu district of Bale [27-31]. Except Acacia mellifera, browse plants produce edible fruits that can be consumed by both man and livestock (Table3). However, majority of the respondents (77.4\%) utilized Acacia mellifera for fencing. This is in line with the findings of Amaha in Somali Regional State for other browse species [28]. Moreover, John and Moses reported that in southern Kenya particularly thorny species like Acacia mellifera and Acacia tortilis used for homestead fence, predator deterrents and livestock sheds. During the dry season herdsmen shake the browse trees of Ziziphus mauritiana to fell down the fruits to the ground naturally and feed livestock especially sheep and goat and humans. Descussants also mentioned that, fruits of Grewia tenax, Grewia ferruginea and Rhus natalensis also are consumed especially by children and women. Similarly, El-Siddig et al reported that fruits and other parts of Grewia tenax contribute significantly to the food and energy needs of rural populations in multiple ways as the fruit is eaten fresh but has commercial potential for consumption from beverages to ice cream, yogurt, porridge and confectionery [32]. Because of its high iron contents, fruits of Grewia tenax are often used in special diets for pregnant women and anemic children. Similarly, the consumption of wild plants seems more common and widespread in food insecure areas, including most dry land areas, where a wide range of spices is consumed, leading to the notion of "famine-foods", plants consumed only at times of food stress, namely drought, war and other hardship periods [33-36]. Group discussion with elders indicated that, the major browse species such as the leaves of Grewia tenax used to cure human wounds and also the smaller stems are used for teeth brushing. In line to this, El Ghazali et al found that leaves and twigs of Grewia tenax are an important component of folk medicine for the treatment of trachoma, tonsillitis, infections and are used as a poultice to treat swelling [37]. Pastoralists had also use Acacia mellifera to improve shelf life, flavor and aroma of milk. Women during group discussion argued that, the stem was used for smoking of milk handling utensils. Similarly, Kedija reported that smoking of milk handling utensils is done to improve aroma and flavor of the milk [38]. Similarly, Chenyambuga, et al. also reported that treating of milk by traditional smoking practiced by different tribes in Tanzania inhibits growth and activity of mesophyllic and thermophilic lactic acid bacteria [39].

\begin{tabular}{|c|c|c|c|c|c|c|}
\hline Uses & A. mellifera & G.ferruginea & G.tembensis & G.tenax & R.natalensis & Z.mauritiana \\
\hline Fence & 77.4 & 0 & 0 & 0 & 0 & 15 \\
\hline Fire wood & 8.6 & 4.3 & 3.2 & 0 & 2.2 & 6.4 \\
\hline For medicinal purpose & 3.2 & 5.4 & 7.5 & 12.9 & 19.3 & 2.2 \\
\hline Smoking milk utensils & 10.8 & 0 & 0 & 0 & 0 & 0 \\
\hline Edible fruit & 0 & 75.3 & 78.5 & 83.8 & 69.9 & 69.9 \\
\hline Shelter for animal & 0 & 3.2 & 6.5 & 1.1 & 0 & 6.5 \\
\hline House construction & 0 & 11.8 & 4.3 & 2.2 & 8.6 & 0 \\
\hline
\end{tabular}

Table 3: Percentage of respondents on multi-use of major browse species in Mieso district ( $\mathrm{N}=93$ ).

Welay K, et al. Traditional Utilization and Chemical Composition of Major Browse Species in Range Lands of Mieso, Ethiopia. J Agri Res 2018, 3(9): 000197. 


\section{Open Access Journal of Agricultural Research}

\section{Chemical Compositions of Major Browse Species}

The lowest $(\mathrm{P}<0.05)$ Crude protein $(\mathrm{CP})$ content was noted for Rhus natalensis. The current $\mathrm{CP}$ value is lower than Mohammed reports in Chifra district of Afar regional state, Ethiopia for Grewia tembensis (22\%) but higher than Helen findings for other browse plant species $[30,40]$. However, the crude protein (CP) content result of the present study is within the range reported by Dicko and Sikena reported for different browse species (6 to $23 \%$ CP) [41]. Variation in nutrient content of browse species is may be because of soil fertility difference and inherent ablity of the plant to accumulate nuturiets from the soil. The CP contents of these browses were higher than the minimum of $7-8 \%$ necessary to provide the minimum ammonia levels required by rumen microorganisms to support optimum rumen activity and required to satisfy the ruminal micro-organism of sheep and goats [42]. The CP values of the current study were also above the requirement for lactation $(12 \% \mathrm{CP})$ and growth $(11.3 \% \mathrm{CP})$ in the diets of ruminants as reported by ARC [43]. This indicates the selected browse plants analaysed in this study may be well used as a protein supplement to low quality feeds such as crop residues due to a higher level of crude protein of all the browse plant species.

\begin{tabular}{|c|c|c|c|c|c|c|}
\hline Species & DM & CP & NDF & ADF & ADL & Ash \\
\hline A.mellifera & $91.6^{\mathrm{e}} \pm 0.04$ & $17.0^{\mathrm{b}} \pm 0.00$ & $40.8^{\mathrm{c}} \pm 0.5$ & $25.3^{\mathrm{c}} \pm 0.1$ & $7.8 \pm 1.1$ & $10.0 \pm 0.02$ \\
\hline G.ferruginea & $93.3^{\mathrm{b}} \pm 0.09$ & $19.0^{\mathrm{a}} \pm 0.17$ & $46.8^{\mathrm{b}} \pm 0.9$ & $30.7^{\mathrm{b}} \pm 2.3$ & $9.5 \pm 0.84$ & $10.0 \pm 0.03$ \\
\hline G.tembensis & $92.7^{\mathrm{c}} \pm 0.09$ & $18.2^{\mathrm{ab}} \pm 0.18$ & $47.3^{\mathrm{b}} \pm 0.5$ & $28.2^{\mathrm{bc}} \pm 0.3$ & $8.5 \pm 0.45$ & $10.1 \pm 0.08$ \\
\hline G. tenax & $92.6^{\mathrm{d}} \pm 0.06$ & $18.7^{\mathrm{a}} \pm 0.57$ & $46.8^{\mathrm{b}} \pm 0.1$ & $30.2^{\mathrm{b}} \pm 0.11$ & $9.2 \pm 0.9$ & $10.0 \pm 0.07$ \\
\hline R.natalensis & $94.0^{\mathrm{a}} \pm 0.2$ & $15.5^{\mathrm{c}} \pm 0.27$ & $65^{\mathrm{a}} \pm 0.3$ & $42.4^{\mathrm{a}} \pm 0.35$ & $10.6 \pm 1.59$ & $9.5 \pm 0.6$ \\
\hline Z.mauritiana & $93.1^{\mathrm{c}} \pm 0.07$ & $18.1^{\mathrm{ab} \pm 0.20}$ & $46.4^{\mathrm{b}} \pm 0.2$ & $24.8^{\mathrm{c}} \pm 0.50$ & $6.9 \pm 0.48$ & $10.1 \pm 0.03$ \\
\hline
\end{tabular}

a,b,c Means with different letters within a column are significantly different $(p<0.05), A D F=$ acid detergent fiber; ADL= acid detergent lignin; $\mathrm{CP}=$ crude protein; $\mathrm{DM}=$ dry matter; $\mathrm{NDF}=$ neutral detergent fiber, $\mathrm{SE}=$ standard error.

Table 4: Chemical composition of major browse species in Mieso district (Mean \pm SE).

Rhus natalensis had significant $(\mathrm{P}<0.05)$ higher neutral detergent fiber (NDF) percentage as compared to the other browse species. Browse species with high NDF content like Rhus natalensis may impose a limitation on feed intake of grazing animals. Similarly NDF is the major determinant of overall forage quality and digestibility, and has direct effect on animal performance [44]. However, camels have higher capacity to utilize fibrous feed material by retaining it in the rumen for longer period, allowing for better digestion [45]. The Acid detergent fiber (ADF) content of Rhus natalensis was also significantly higher $(\mathrm{P}<0.05)$ than the other species. Acacia mellifera and ziziphus mauritania had significant $(\mathrm{P}<0.05)$ lower ADF percentage from Grewia ferruginea and Grewia tenax. Lower values of ADF in these leaves of browse species indicate good potential as ruminant feed [46]. Those browse species with higher ADF content may have lower digestibility since digestibility of feeds and ADF content are negatively correlated [47]. However, the NDF and ADF content of the current study are within the range (24-61\% and $17-61 \%$ ) respectively documented for forages used in ruminant feeding $[48,49]$. ADL and ash values of the browse species were not significantly $(P>0.05)$ different. This is suggesting that the intake of the tested browses will not be hindered.

\section{Conclusion}

Browse species in the study area constitute a valuable source of feed for the animals and source of food for the humans and thus, may greatly contribute to the nutritional need of livestock and to the livelihood of pastoralists in the area at large. Therefore, awareness creation strategies and developing means should be targeted to maintain those valuable plants to have a sustainable livestock production in the area. Browse species had also other traditional uses such as their role in medicinal value. Therefore, in-depth studies on the nutritional and medicinal and/or other traditional values of the browse species used in this study and other should be conducted.

\section{Conflict of Interest}

The authors declare no conflicts of interest.

\section{References}

1. Ahamefule FO, Ibeawuchi JA, Agu M (2006) Comparative evaluation of some forages offered to 


\section{Open Access Journal of Agricultural Research}

goats in Umudike, Southeastern Nigeria. Journal of Sustainable and Agricultural Research.

2. Ibeawuchi JA, Ahamefule FO, Oche JE (2002) An assessment of the nutritive value of the browse plants in Makurdi, Nigeria. Nig Agric J 33: 128-135.

3. Smith OB (1992) Fodder trees and fodder shrubs in range and farming systems in tropical humid Africa. pp: 43-60.

4. Le Houerou HN (1980) Chemical composition and nutritive value of browse in tropical West Africa. In: Le Houérou HN (Ed), Browse in Africa, the current state of knowledge. ILCA, Addis Ababa, Ethiopia, pp: 261-289.

5. Devendra C (1990) The use of shrubs and tree fodders by ruminants. In: Devendra C (Ed), Shrubs and Tree Fodders for Farm Animals. Proceedings of a Workshop, 24-29 July 1989, Denpasar, Indonesia. International Development Research Center, Ottawa, Canada.

6. Atta-Krah AN (1990) Fodder trees and shrubs in tropical Africa: Importance, availability and pattern of utilization. Center for Agricultural and Rural Cooperation pp: 118-138.

7. Woodward A, Coppock DL (1995) Role of plant defensive mechanism in the utilization of native browse plants in Southern Ethiopia. Agroforestry Systems 32(2): 147-161.

8. Ebro A, Smit GN, Snyman HA (2005) The influence of woody plants and livestock grazing on grass species composition, yield and soil nutrients in the Middle Awash Valley of Ethiopia. Journal of Arid Environments 60(2): 343-358.

9. Alemu TD, Farah KO, Mbuvi DM (1998) Impact of land use on woody vegetation in semi-arid area of Abala district, north Afar, Ethiopia. University of Nairobi.

10. Abule E, Snyman HA, Smit GN (2005) Comparisons of pastoralists perceptions about rangeland resource utilization in the Middle Awash Valley of Ethiopia. Journal of Environmental Management 75(1): 21-35.

11. Amaha Kassahun (2003) Pastoralism and the need for future intervention in pastoral areas of Ethiopia. Annual review of National Dry Land Agricultural Research Systems, Addis Ababa, Ethiopia.
12. Gemedo-Dalle, Maass BL, Isselstein J (2006) Rangeland condition and trend in the semi-arid Borana lowlands, southern Oromia, Ethiopia. African Journal of Range and Forage Science 23(1): 49-58.

13. Alemayehu, M., 2006. Range Management for Eastern Africa: Concept and Practice sponsored by RPSUD and printed by A.A.U.printed press. Addis Ababa, Ethiopia pp: 118-119.

14. IPMS (2006) Improving Productivity and Market Success. Pilot Learning Site of Mieso woreda.

15. Legesse G (2008) Productive and economic performance of small ruminants in two production systems of the highlands of Ethiopia. University of Hohenheim, Stuttgart, Germany.

16. Bamualin A, Jones RJ, Murray RM (1980) Nutritive value of tropical browse legumes in the dry season. Proceeding of Australian Society of Animal Production 13: 229-232.

17. Tesfaye Z (2009) Vegetation Composition, Biomass Production, and Condition in Bordodde Rangeland, west hararghe, Oromiya Ethiopia.

18. ILCA (1990) Livestock system research manualVolume 1. International Livestock Centre for Africa (ILCA) 1(1): 287.

19. Hedberg I, Edwards S (1989) Flora of Ethiopia. 3: 660.

20. Cufodontis G (1953-1972) Enumeratio Plantaraumaetiopiae. Spermatophyte. Bulletin de la Jardin Botanique de I'Etat des Bruselles 1: 23-42.

21. AOAC (1990) Official Methods of Analysis. In: AOAC (15th Edn.), Arlington, Virginia, USA pp: 1298.

22. Van Soest PJ, Robertson JB (1985) Analysis of forages and fibrous foods. Anim Sci Cornell Univ Press, Ithaca, NY.

23. SPSS (Statistical Package for Social Sciences). SPSS Base 10.0. Application Guide. SPSS Inc.

24. SAS (2002) SAS user's guide (version 9, 3rd Edn), SAS Inst, Inc Cary, NC.

25. Melaku S, Nigatu N, Aregawi T (2010) Chemical composition, in vitro dry matter digestibility and insacco degradability of selected browse species used as animal feeds under semi-arid conditions in 


\section{Open Access Journal of Agricultural Research}

Northern Ethiopia. Agroforestry Systems 80(2): 173184.

26. Aregawi T, Melaku S, Nigatu L (2008) Management and utilization of browse species as livestock feed in semi-arid district of North Ethiopia. 20(86).

27. Coppock DL (1993) The Boran Pleatue of Southern Ethiopia: Synthesis of Pastoral Research, Development and Change, 1980-91. ILCA systems study pp: 393.

28. Gezahegn AK (2006) Characterization of the Rangeland Resources and Dynamics of the Pastoral Production Systems in the Somali Region of Ethiopia. University of Free State.

29. Tsehay L (2007) Woody and herbaceous species composition and the condition of the rangelands in Shinile zone of condition of the rangelands in Shinile zone of Somali regional state, Ethiopia. An M Sc Thesis Presented to the School of Graduate Studies of Haramaya University, Ethiopia

30. Asfaw H (2009) Feed resource availability, biomass production, nutritional characterization and pattern of utilization in Gursum district, Somali region, eastern Ethiopia. An M Sc thesis presented to the school of Graduate studies of Haramaya university, Ethiopia.

31. Abate T, Ebro A, Nigatu L (2010) Traditional rangeland resource utilisation practices and pastoralists' perceptions on land degradation in south-east Ethiopia. Tropical Grasslands 44: 202-212.

32. El-Siddig K, El Tahir BA, Ebert G (2003) Grewia tenaxa potential new small fruit for the Sudan. Deutscher Tropentag, Conference on International Agricultural Research for Development in Göttingen pp: 309.

33. Attere F, Zedan H, Ng NQ, Perrino P (1991) Crop genetic resource of Africa. 1: 26-30.

34. Zemede Asfaw (1997) Survey of Indigenous Food Plants, their Preparations and Home Gardens in Ethiopia. ICIPE Science Press, Nairobi, Kenya.

35. Asfaw Z, Tadesse M (2001) Prospects of sustainable use and development of wild food plants in Ethiopia. Economic Botany 55(1): 47-62.

36. Pol JLV, Teketay D, Yemshaw Y (2002) Forest is not only wood: The importance of non-wood forest products for the food security of rural households in Ethiopia. pp: 16-31.

37. El Ghazali GEB, El Tohami MS, El Egami B (1994) Medicinal plants of the Sudan: medicinal plants of the White Nile provinces. Khartoum University Press, Khartoum.

38. Hussen K (2007) Characterization of Milk Production Systems and Opportunity for Market Orientation: A Case Study of Meiso District, Oromiya Region, Ethiopia. An MSc Thesis Presented to the School of Graduate Studies of Haramaya University, Ethiopia.

39. Chenyambuga SW, Goromela EH, Ryoba R, Kurwijila RL (1993) A study on the effect of traditional African smoke treatment of milk on the organoleptic and keeping quality of sour milk.

40. Abdulatife M (2009) Assessment of pastoral perceptions, range condition and chemical composition of major feed resources in chifra district of afar regional state, Ethiopia.

41. Dicko, MS, Sikena LK (1992) Feeding behavior, quantitative and qualitative intake of browse by domestic ruminants. 102: 129-144.

42. Norton BW (2003) Studies of the nutrition of the Australian goat. Thesis (D Agr Sc), University of Melbourne.

43. ARC (1984) The Nutrient Requirements of Ruminant Livestock. Commonwealth Agricultural Bureaux pp: 351.

44. Linn J (2004) Forage fiber analysis-what does it mean? In: Nutrition management guides, University of Minnosota and Paul Windshiti, Hubbord daily services, USA.

45. Lechner-Doll M, Rutawenda T, Schwartz HJ, Schultka W (1990) Seasonal changes of ingesta Mean retention time and forestomach fluid volume in indigenous cattle,sheep,and goat grazing a thorn bush savannah pasture in Kenya. Journal of agriculture science combridge 115(3): 409-420.

46. Bakshi MPS, Wadhwa M (2007) Tree leaves as complete feed for goat kids. Small Ruminant Research 69: 74-78. 


\section{Open Access Journal of Agricultural Research}

47. McDonald P, Edwards RA, Greenhalgh JFD (2002) Animal Nutrition (6th Edn), Pearson Educational Limited. Edinburgh, Great Britain pp: 543.

48. Topps JH (1992) Potential composition and use of legumes shrubs and trees as fodder for livestock in the tropics. Journal of Agricultural Science Cambridge 118: $1-8$.
49. Budi T, Wina E (1995) Chemical evaluation of shrubs legumes. Indonesia Agricultural Research Dietary Journal 17: 147-158.

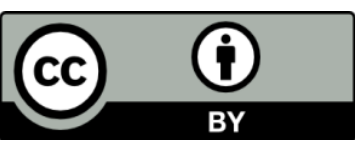

